\title{
Vicious and Virtuous Cycles and the Role of External Non-government Actors in Community Forestry in Oaxaca and Michoacán, Mexico
}

\author{
James A. Barsimantov
}

Published online: 25 September 2009

(C) The Author(s) 2009. This article is published with open access at Springerlink.com

\begin{abstract}
Community forestry offers potential for socioeconomic benefits while maintaining ecosystem services. In Mexico, government and donor efforts to develop this sector focus on issues within forest communities. Often overlooked are effects of external non-government actors (NGOs and foresters) as links or barriers between communities and funding, capacity building, and technical support. To analyze the role of these actors, I analyze household survey and interview data from 11 communities with varying levels of vertical integration of forestry production in states with divergent records of community forestry, Oaxaca and Michoacán. Results suggest that strong community governance is necessary but not sufficient for vertical integration, and strong interactions with nongovernment actors are critical. These actors, operating within the existing framework of government regulations, have a range of incentives for engaging communities. Availability of these actors motivated by concern for community capacity instead of timber income may be a determinant of community forestry development.
\end{abstract}

Keywords Community forestry . Common property .

Mexico $\cdot$ NGO

\section{Introduction}

Community forestry in Mexico has been acclaimed as a global model for sustainable forest resource management

J. A. Barsimantov $(\bowtie)$

Department of Environmental Studies, University of California,

Santa Cruz,

1156 High Street,

Santa Cruz, CA 95064, USA

e-mail: jbarsima@ucsc.edu
(Bray et al. 2003). Mexico holds the largest number of communally owned forestry parcels certified by the Forest Stewardship Council in the world (FSC 2007). In over 25 years of investment, the work of the Mexican government, international donors, the World Bank, and NGOs has led to examples of high levels of community participation in forest management and the production of value-added wood products, resulting in economic benefits and maintenance of ecosystem services (Bray et al. 2005).

Yet roughly 500,000 ha are deforested annually in Mexico, equivalent to a yearly rate of $1.02 \%$ for highland pine/oak/fir forests and $2.06 \%$ for tropical forests between 1993 and 2000 (Velazquez et al. 2002). Although much of this deforestation occurs in forest ecosystems with little timber value, forests suitable for timber management continue to suffer from deforestation and degradation (World Bank 1995; Jardel 1998, 2006). Community forestry has become an accepted development model for rural communities, promising economic benefits for rural people as well as an alternative to land use change and forest degradation (Bray et al. 2005). But while a small percentage of communities continue to improve forest management practices and produce value-added wood products, the large majority of community forestry programs have stagnated. The reason why the social and environmental successes in exemplar communities are not reproduced in more community forestry programs is perhaps the most pressing question in community forest management in Mexico today, and development workers usually point to a lack of strong internal organization in forest communities. Often overlooked, however, is the role of external non-government actors (NGOs and foresters) in the development or stagnation of community forestry. As the main link between forest communities and funding, capacity building, and technical support, I argue that their 
role is of critical importance. In addition, their effect is selfreinforcing. This leads to what I call virtuous cycles, in which certain communities continue to improve with the help of certain types external actors, and vicious cycles, in which community forests degrade under the control of other types of external actors. I first develop a typology of external non-government actors which focuses on the degree to which they are motivated by income from timber harvesting versus grants from donor agencies for community development. I then use a comparative case study of 11 forest communities in Michoacán and Oaxaca using quantitative and qualitative data to illustrate the importance of external actors in creating the community forestry landscape in Mexico.

\section{Forest Governance in Common Property}

With over $80 \%$ of Mexico's forests under a common property regime (Yates 1981), effective local governance of commonly owned forests is crucial to maintain ecosystem services and create economic benefits for forest communities. Collective action theory (Olson 1965) as applied to common property (Ostrom 1990) aims to understand the conditions under which groups of people cooperate to manage commonly owned resources. Effective collective action in the commons is influenced by three sets of factors: characteristics of the user group, characteristics of the resource, and external influences (Ostrom 1990), and variations in these three sets of factors make it more or less likely that collective action will ensue. Most research on management of commonly owned forests has focused on the first two sets of factors, including extensive work on rule-making and enforcement, leadership, group size, and heterogeneity, and characteristics of the resource (Wade 1988; Ostrom 1990; Gibson et al. 2000; Poteete and Ostrom 2004).

The large and growing body of literature on common property management rarely focuses on the third set of factors: external influences on the community. Commons management invariably takes place within a political economic context whose influence in some cases may matter more than internal organization (McCay and Jentoft 1998; Agrawal 2001). According to Ostrom (1990), external governance can either facilitate the creation and enforcement of rules or impede local governance by imposing generalized rules or engaging in corruption. In Mexico, research on the external context of community forestry has focused on failures in management resulting from the lack of coordination between state and local authorities in the Monarch Butterfly Reserve in Michoacán (Tucker 2004); on a local logging ban that created disincentives for sustainable timber management in the Lake Pátzcuaro basin in Michoacán (Klooster 2003); and on federal reforms of land tenure and forestry laws in Durango and Quintana Roo (Taylor and Zabin 2000; Taylor 2000, 2003).

Yet there is gap in research on the role of nongovernment actors in community forestry, in Mexico and in general. Political mediators can both gain access to resources and power as well as perpetuate state domination in communities in Mexico (de la Peña 1992; de Vries 2002). However, this lens is seldom applied to a common property analysis of resource management. Bray (2000) and Vargas-Prieto (1998) point out the positive role of ejido unions in forming community forestry programs in Quintana Roo, Mexico, but do not explore cases in which external actors may stymie community development. The lack of extensive research on this topic is surprising given that nearly every community with a forestry program relies on the services of an external non-government actor. As interdisciplinary environmental science attempts to bridge the gap between research and practice, the topic of this paper is of special pertinence to understand how development efforts affect commons management.

Non-government actors form a key link between beneficiaries of development assistance (communities) and donors (Ostrom et al. 2002). They can form a link between the state and the communities so that opposing forces in the government can be muted and new policies can be put into practice (Vargas-Prieto 1998). In the commercialization of non-timber forest products, the importance of nongovernment actors was identified in almost every stage of collecting and marketing resources (Marshall et al. 2003). Yet non-government actors are often given responsibility for development by the central government without first determining their capacity to do so (Haley and Clayton 2003), and some non-government actors may siphon off development funds that are meant for beneficiaries (Meyer 1995). Thus, the influence of non-government actors can either be positive or negative, and this study aims to both provide evidence of the key points at which nongovernment actors play a role and identify the incentives that lead to vicious and virtuous cycles.

\section{Community Forestry in Mexico}

Community forestry in Mexico began in the late 1970s when concessions to parastatal timber companies were nearing expiration and a handful of communities in Oaxaca and Durango organized to attain the right to harvest timber from land under their control (ASETECO 2002; Bray and Merino 2004). The Forestry Law of 1986 established community forestry in Mexico by canceling concessions and formally recognizing the rights of communities to manage forest resources and contract forestry services (Merino 2004). Most of Mexico's highly successful 
community forestry programs (Chapela Mendoza 1999; Velazquez et al. 2003; Bray et al. 2004) were initiated in the late 1970s and early 1980s as a result of the grassroots community forestry movement and subsequent government sponsored community forestry development programs. Since the end of this initial period of growth, community forestry in Mexico has grown in two directions. First, communities that had created stable programs in the 1980s continued to grow and expand, training local foresters, strengthening community governance institutions, acquiring infrastructure, and even attaining FSC certification. Second, more communities have attained permits for forest management; currently there are nearly 2,000 active permits in Mexico's commonly owned forests (Antinori et al. 2004).

Mexico's forestry programs vary immensely in the level of participation in local forest governance, the ecological sustainability of forest management, and the type of wood products created. The National Forestry Commission (CONAFOR) classifies forestry communities based on their level of vertical integration in the productive chain of wood processing. This system includes four types of communities: (1) communities with harvestable timber volume but no active forest management plan, (2) communities that charge a stumpage fee to timber companies who implement forest management, (3) communities that fell timber and transport logs to sell to an external saw mill, and (4) communities that own a saw mill and produce sawn lumber or finished wood products. Only about $14 \%$ of the 2,000 active permits in Mexico are Type 4 forestry programs, ${ }^{1}$ and most of these are communities that had initiated stable programs in the early 1980s (Ramirez 2005, personal communication). While the level of vertical integration is not in itself a criterion to determine success in forest management, higher levels of vertical integration usually reflect stable organization, high levels of community participation, community control of forest resources, existence of sound financial management structures, and more careful ecological practices, all of which are criteria often used to measure success in community forestry (Pagdee $e t$ al. 2006). In addition, nearly all communities with FSC certification are Type 4, which reflects both social and ecological sustainability criteria. The large majority of communities with forestry permits in Mexico, however, are Type 2 communities that participate in few forest management activities, instead contracting to timber companies and private foresters, which may raise ques-

\footnotetext{
${ }^{1}$ Data compiled from the National Survey of Community-Managed Forestry in Mexico (Phase 1). Principal Investigators: Camille M. Antinori, Juan Manuel Torres-Rojo, Octavio Magaña, David B. Bray, 2006.
}

tions about the social and ecological outcomes of these programs.

\section{Community Forestry in Oaxaca and Michoacán}

The states of Michoacán and Oaxaca both contain large volumes of pine species, the dominant species harvested for timber in Mexico, ranking fourth and sixth in total forest volume nationwide (SEMARNAT 2004). Oaxaca, especially the Sierra Juarez region, is perhaps the most widely renowned region in the country for communities that produce sawn wood and finished wood products (Type 4 communities) and that have attained FSC Certification (Table 1). Michoacán, on the other hand, has a high percentage of communities that contract timber harvesting services to local timber companies (Type 2 communities), leaving most of forest management to private foresters. In addition, illegal logging is widespread throughout Michoacán, accounting for roughly half of timber harvested (Pimentel Ramirez 2005), and is less prevalent in Oaxaca (Galeote 2006).

Achievements of the government-run community forestry development program, the Program for Communities and Forest Management (PROCYMAF), have also not been equivalent in the two states. From 2004 to 2006, Type 4 communities increased $16 \%$ (from 37 to 43 ) in Oaxaca and only $1 \%$ in Michoacán (from 20 to 21 communities). Type 3 communities increased 31\% (from 42 to 55) in Oaxaca and decreased 2\% (from 15 to 12) in Michoacán. Finally, in both states Type 2 communities increased about $10 \%$ (Rodriguez Salazar 2006, unpublished manuscript), suggesting that acquiring a forest management permit is not as difficult as appropriating forest management activities. In other words, forest communities in Oaxaca continue to realize greater capacity while those in Michoacán remain relatively stagnant.

A complex set of interrelated historical, geographical, cultural and political factors may explain why Oaxaca has a more advanced forestry sector and why Michoacán has higher levels of illegal logging. Forested regions of Michoacán were settled by the Spanish in the colonial period and subsequently more haciendas were established there than in Oaxaca (Altman and Lockhart 1976; Chance 1989). This was perhaps due to Michoacán's relatively flatter terrain that allowed for more accessible settlement and agriculture. As a result, traditional indigenous governance systems may have been more disrupted in Michoacán. In addition, timber concessions from the late 1950s to the early 1980s in Oaxaca have played a role in educating locals on forest management practices (Antinori 2000), and logging bans in Michoacán during the same time period may have created an incentive for illegal extraction. Illegal logging in Michoacán may be attributed to a more 
Table 1 Number and percent of communities by level of vertical integration in Oaxaca and Michoacán and in study regions

\begin{tabular}{lllll}
\hline $\begin{array}{l}\text { Forestry } \\
\text { type }\end{array}$ & Oaxaca & & \multicolumn{2}{l}{ Michoacán } \\
\cline { 2 - 3 } & Statewide & $\begin{array}{l}\text { Study region: the Sierra Juarez (Districts of Ixtlán, } \\
\text { Etla, and Villa Alta) }\end{array}$ & Statewide & $\begin{array}{l}\text { Study region: municipalities of Ario de Rosales, } \\
\text { Salvador Escalante and Tacámbaro }\end{array}$ \\
\hline 2 & $74(50 \%)$ & $13(35 \%)$ & $138(80 \%)$ & $18(78 \%)$ \\
3 & $42(28 \%)$ & $11(30 \%)$ & $24(14 \%)$ & $4(17 \%)$ \\
4 & $32(22 \%)$ & $13(35 \%)$ & $11(6 \%)$ & $1(4 \%)$ \\
Total & $148(100 \%)$ & $37(100 \%)$ & $173(100 \%)$ & $23(100 \%)$ \\
\hline
\end{tabular}

National Survey of Community-Managed Forestry in Mexico (phase 1), ibid. Reliable data for type 1 communities were not available

developed timber processing industry that has twice the capacity necessary to process the legal timber volume (Pimentel Ramirez 2005), greater availability of capital in a relatively wealthier state, a more developed road network, proximity to markets in Mexico City, and, as a result of increased opportunity for resource extraction, corruption among foresters and government officials (Navia Antezana 2006). The problem, however, is overdetermined; none of these reasons alone can explain observed differences in the development of community forestry and illegal logging in the two states, and all of these reasons probably contribute.

These historical reasons together can explain why Oaxaca and Michoacán entered the era of community forestry in the early 1980 s in different situations. However, government and non-government interviewees suggested that Oaxaca communities have higher levels of vertical integration than those in Michoacán because they have stronger internal governance structures (Ramirez 2005, personal communication). The historical reasons mentioned above are thought to have an effect on internal community governance, when in fact, as I will demonstrate, these historical reasons also created very different landscapes of external non-government actors in each state. Due to differing histories of extractive practices in Michoacán and Oaxaca, variations of the forest policy framework evolved in each state, and this in turn has reinforced the types of activities in which external non-government actors engage.

\section{Analytical Framework: A Typology of External Non-government Actors}

In most communities, every step of community forestry is negotiated with the help of an external non-government actor. In fact, not a single community forestry program was initiated without the aid of these actors, and only a few have gained sufficient capacity to become independent of external support. Mexico's Type 4 'success stories' required extensive external assistance, the most important compo- nents of which were capacity building and community organizing, rather than monetary assistance or technical services (Chapela Mendoza 1999; ASETECO 2002). Thus, the availability and quality of external actors that promote these components may be a key factor in determining the outcomes of community forestry.

The roles of external non-government actors in community forestry fall into two categories: community development and timber extraction. Community development activities are focused on the community, its leaders and its assembly, and involve capacity building in forest management, accountability with community funds, rule-making and enforcement, and soliciting funds from government programs or international donors. Timber extraction activities, on the other hand, are directed at the forest, rather than the community, even though permission from the community is required. These activities involve writing management plans, demarcating trees for felling, and navigating government bureaucracy. In communities with low participation in forest management, these activities may occur with little community oversight. External non-government actors can either be a catalyst for the growth of a forestry program and better management practices or a bottleneck that prevents its development and contributes to degradation. Much of this depends on the motivations of the nongovernment actor; whether the external actor is more interested in community development activities or timber extraction activities.

At one end of the spectrum of non-government actors are traditional private foresters who are trained in timber extraction activities and are paid a fee per cubic meter of timber demarcated for felling. Thus, it is in the interests of foresters to demarcate trees for felling that will provide the most and best quality wood, and greater community capacity for forest management does not lead to greater profit for the forester. At the other end of the spectrum are non-government organizations (NGOs) that focus on community development. Aside from altruism for the environment and rural people, which is arguably a strong motivation of these actors, they are motivated to implement 
successful projects (Ostrom et al. 2002). Projects that create tangible outcomes in communities lead to more and larger grants from donors. Unsuccessful projects may lead to the inability to attain funds for similar projects.

Between these two extremes are various types of hybrid external actors. Some private foresters have gained experience in community development work, either through work in government programs or research institutions. Some NGOs employ foresters or contract forestry work to trusted private foresters, and thus also perform timber extraction activities. These hybrid organizations have varying degrees of both motivations depending on the composition of their staff and the types of projects they take on. Finally, some Type 4 communities have become nearly independent of external non-government actors, forming their own staff that carries out timber extraction activities and contracts with NGOs for some community development activities. In all cases encountered, this internal staff is paid a salary by the community which is not dependent on the amount of timber harvested. This phenomenon can be seen as the outcome of extensive community development activities on the part of external non-government actors. Figure 1 shows a continuum of motivations of external non-government actors. ${ }^{2}$ I will hereafter refer to the types of external actors as TEO (timber extraction oriented) actors, CDO (community development oriented) actors, and hybrid actors.

I argue that (1) strong internal governance is necessary but not sufficient for community appropriation of forest management; external non-government actors play a key role, and (2) the actions of external non-government actors on community forestry development can be understood through their motivations for engaging in their activities.

\section{Research Design and Methodology}

I selected case study communities from a representative region of Michoacán and the most highly vertically integrated forestry region in Oaxaca because I aim to understand why some communities attain higher levels of vertical integration than others and whether this situation is related to state-level differences. In Oaxaca I selected case study communities from the Sierra Juarez, composed of the districts of Ixtlán, Etla, and Villa Alta, because it is above the state average in its percent of Type 4 communities (see Table 1). In Michoacán, I selected communities from the Central Highlands municipalities of Ario de Rosales and Salvador Escalate. Michoacán contains three general

\footnotetext{
${ }^{2}$ Another category of external actors, second-level institutions or community/ejido unions, can be either hybrid actors or internal organizations depending on whether communities run the union or are subject to outsider decisions.
}

regions where extensive forest management occurs: the Central Highlands, Eastern Michoacán, and the Coast Range. I selected communities from the Central Highlands because (1) it suffers from the same issues of illegal logging and poor management as other regions in the state (Pimentel Ramirez 2005), (2) it is not distant from population centers like the remote Coast Range and (3) it does not have the unique and problematic relationships between external institutions and communities that resulted from the creation of the Monarch Butterfly Reserve in Eastern Michoacán (Tucker 2004). Within the Central Highlands, I selected a non-indigenous region because the Meseta Purepecha within the Central Highlands is the only indigenous region of the state and is therefore not representative of ethnicity in the state.

In each region, I selected communities that varied in their level of vertical integration and attempted to control for exogenous factors that may influence the success of a forest management program, including population, forest area, and topography (Table 2, Fig. 1). While population and area vary between communities, this variation is not skewed towards one type of community or one state. A topographic roughness measure indicates that Oaxaca communities are steeper than those in Michoacán, but within each state the topography of communities is comparable. To control for forest type and distance to population centers, each community shares a boundary with at least one other case study community.

Within each region, I selected communities to reflect the distribution of vertical integration of each state, selecting additional Type 1 and 2 communities in Michoacán for a total of seven communities and selecting one of each category in Oaxaca for a total of four communities (Table 1). While Type 4 communities exist in Michoacán, they are scarce and none were found in the case study region. Even though choosing a nonindigenous area in the Central Highlands made it impossible to select a Type 4 community in Michoacán, the benefits of representativeness that the region provided, along with the fact that my selection strategy aimed to reflect the actual distribution of vertical integration types in the state, outweighed the costs of a less balanced research design (Fig. 2).

A household survey was applied in a $20 \%$ random sample of households in each community $(n=382)$. A random sample was taken from a list all households in the community that was either available through the community authorities or created with their help. Questions were developed with the aid of a local NGO and were pretested in the first community visited in eight households. Surveys were administered orally by three research assistants from Mexican universities, and in each community a local resident was hired to locate selected houses 


\begin{tabular}{lllc}
$\begin{array}{l}\text { Timber Extraction } \\
\text { Oriented (TEO) Actors }\end{array}$ & \multicolumn{1}{c}{$\begin{array}{l}\text { Community Development } \\
\text { Oriented (CDO) Actors }\end{array}$} \\
$\begin{array}{l}\text { traditional private } \\
\text { foresters }\end{array}$ & $\begin{array}{l}\text { private foresters with } \\
\text { development experience }\end{array}$ & $\begin{array}{l}\text { NGOs with } \\
\text { foresters on staff }\end{array}$ & $\begin{array}{l}\text { NGOs that contract } \\
\text { forestry work }\end{array}$
\end{tabular}

Fig. 1 The spectrum of external non-government actors

and introduce survey administrators to heads of households. Surveys required between $40 \mathrm{~min}$ and $1 \mathrm{~h}$ to complete and response rates were between $90 \%$ and $100 \%$ in each community. The survey contained questions pertaining to the entire household as well as specifically to the head of the household and was organized into five sections: (1) household demographics, (2) employment and income sources, (3) agricultural production, (4) community participation, and (5) use of commonlyowned natural resources. Data were entered into an excel spreadsheet by research assistants, and analysis was conducted with the SAS statistical package.

In addition, in each community I conducted between eight and 12 open-ended interviews with local authorities, locals with knowledge of forest use and management, and older community members with knowledge of community history, as well as 44 interviews with government officials (23 interviews), NGO staff (seven), private foresters (ten), and timber companies (four). I used a snowball sampling technique starting with local authorities and government officials. For each community interview I selected from a list of potential questions, depending on the knowledge that I found each interviewee to possess, including questions on forest use history, communal governance, employment patterns, infrastructure and social services, use of income from timber harvests, opinions of external non-government actors, capacity building for forest management, and participation in development projects. Questions for external actor interviews pertained to individuals' knowledge of case study communities, interactions in general with forest communities, the forestry sector in the state, illegal logging activities, and the success of government sponsored development programs. All interviews were recorded on a digital voice recorder except for two respondents who asked not to be recorded, and recordings were analyzed qualitatively to understand causal mechanisms of relationships found in quantitative analysis.

Table 2 Characteristics of case study communities

\begin{tabular}{|c|c|c|c|c|c|c|}
\hline & $\begin{array}{l}\text { Forestry } \\
\text { type }\end{array}$ & $\begin{array}{l}\text { Total surface } \\
\text { area }(\text { ha })^{\mathrm{a}}\end{array}$ & $\begin{array}{l}\text { Forested surface } \\
\text { area }(\mathrm{ha})^{\mathrm{a}}\end{array}$ & $\begin{array}{l}\text { Annual permitted } \\
\text { volume }\left(\mathrm{m}^{3}\right)^{\mathrm{a}}\end{array}$ & Total population ${ }^{\mathrm{b}}$ & $\begin{array}{l}\text { Topographic } \\
\text { roughness }^{c}\end{array}$ \\
\hline \multicolumn{7}{|l|}{ Michoacán } \\
\hline El Oyamel & 3 & 679 & 634 & 5,612 & 337 & 1.029 \\
\hline Las Lomas & 2 & 1,116 & 597 & 970 & 794 & 1.015 \\
\hline San Juan & 2 & 971 & 2,006 & 2,100 & 748 & 1.027 \\
\hline La Capilla & 2 & 2,144 & 1,619 & 3,849 & 633 & 1.031 \\
\hline El Cajoncito & 1 & 946 & 140 & No permit & 537 & 1.030 \\
\hline Las Palmas & 1 & 3,328 & 1,106 & No permit & 710 & 1.033 \\
\hline San Gustavo & 1 & 1,623 & 156 & No permit & 1,021 & 1.009 \\
\hline \multicolumn{7}{|l|}{ Oaxaca } \\
\hline Palo Verde & 4 & 1,269 & 850 & 3,197 & 724 & 1.080 \\
\hline Buenos Aires & 3 & 2,219 & 1,433 & 2,599 & 280 & 1.120 \\
\hline Picachos & 2 & 5,690 & 4,646 & 9,024 & 292 & 1.069 \\
\hline El Rincon & 1 & 6,364 & 5,278 & No permit & 789 & 1.187 \\
\hline
\end{tabular}

Community names have been changed to pseudonyms to maintain anonymity of respondents

${ }^{a}$ Data obtained from the Secretariat of the Environment (SEMARNAT) in each state

${ }^{\mathrm{b}}$ Data obtained from 2005 Population Count (INEGI)

${ }^{\mathrm{c}}$ This is a measure of rugosity created using digital elevation models and ArcView plugin Benthic Terrain Modeler. Rugosity, as defined here, is the mean of each cell's ratio between the surface area and planar area in the region of interest. Values from 1 to 5 are given to each cell, from $1=$ flat to $5=$ steep. For more information see (http://www.csc.noaa.gov/products/btm/) 
Fig. 2 Location of study states, study regions, and case study communities

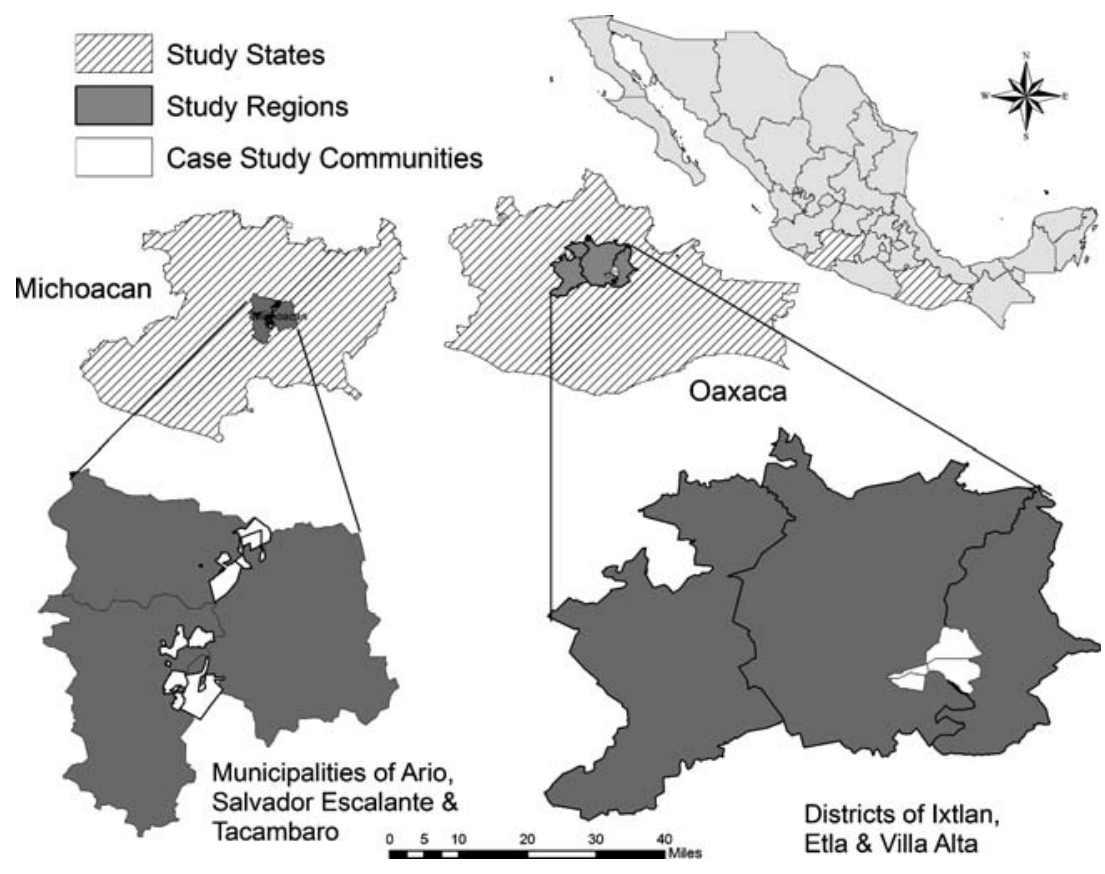

\section{Survey Results}

If the level of vertical integration (type) of forestry programs and its associated outcomes are related only to the strength of internal organization of a community, there should be a clear relationship between survey questions measuring strength of organization and forestry type. This should hold true across both case study states because this pattern would not be dependent on factors external to the community. However, survey analysis results on questions that measure internal organization - management of funds, trust in leadership, and participation - show that this pattern exists in Michoacán case study communities but not in Oaxaca (Table 3). In Michoacán, heads of households in higher forestry type communities responded with significantly higher values on these variables. In Oaxaca, however, internal organization across all communities was universally strong, even in communities with low forestry types. These findings were similar for three other questions not included in Table 3 on community governance: attendance at community assemblies, reporting rulebreakers, and trust in other community members. While these six questions are not a complete measure of community governance, these findings suggest that strong internal organization is necessary but not sufficient for achieving a higher forestry type.

A survey question that measured heads of household's trust in their forester showed a markedly different pattern. I use this question as a proxy for the strength of interaction with the forester, including the forester's focus on community development and the community's ability to attract and work with a trustworthy forester. A high level of trust in the

Table 3 Internal organization: results of factorial ANOVA by forestry type and state

\begin{tabular}{|c|c|c|c|c|c|c|}
\hline \multirow[t]{2}{*}{ Forestry type } & \multicolumn{2}{|c|}{$\begin{array}{l}\text { Statement } 1 \text { : communal funds are } \\
\text { managed well and for the benefit of the } \\
\text { community }\end{array}$} & \multicolumn{2}{|c|}{$\begin{array}{l}\text { Statement } 2 \text { : community leaders are } \\
\text { working well for the advancement of the } \\
\text { community }\end{array}$} & \multicolumn{2}{|c|}{$\begin{array}{l}\text { Statement } 3 \text { : my opinion is considered } \\
\text { during community assemblies }\end{array}$} \\
\hline & Michoacán & Oaxaca & Michoacán & Oaxaca & Michoacán & Oaxaca \\
\hline 1 & $2.8(0.14)[\mathrm{a}]$ & $4.3(0.22)[\mathrm{c}]$ & $2.3(0.14)[\mathrm{a}]$ & $4.3(0.24)[b, c]$ & $2.7(0.13)[\mathrm{a}]$ & $4.7(0.14)[\mathrm{d}]$ \\
\hline 2 & $3.1(0.23)[\mathrm{a}, \mathrm{b}]$ & $4.3(0.21)[\mathrm{c}]$ & $2.4(0.19)[\mathrm{a}]$ & $4.3(0.17)[b, c]$ & $3.0(0.17)[\mathrm{a}, \mathrm{b}]$ & $4.6(0.16)[\mathrm{c}, \mathrm{d}]$ \\
\hline 3 & $4.1(0.22)[b, c]$ & $4.5(0.21)[\mathrm{c}]$ & $3.8(0.29)[\mathrm{b}]$ & $4.7(0.12)[\mathrm{c}]$ & $3.8(0.25)[\mathrm{b}, \mathrm{c}]$ & $4.4(0.22)[\mathrm{c}, \mathrm{d}]$ \\
\hline 4 & & $4.6(0.10)[\mathrm{c}]$ & & $4.6(0.15)[b, c]$ & & $4.7(0.12)[\mathrm{d}]$ \\
\hline \multicolumn{3}{|c|}{ Type main effect $p<0.01$} & \multicolumn{2}{|l|}{$p<0.001$} & \multicolumn{2}{|l|}{ Not significant } \\
\hline \multicolumn{3}{|c|}{ State main effect $p<0.001$} & \multicolumn{2}{|l|}{$p<0.001$} & \multicolumn{2}{|l|}{$p<0.001$} \\
\hline
\end{tabular}

Respondents were asked the extent to which they agreed to statements on a Likert-scale of 1 (total disagreement) to 5 (total agreement). Standard errors are in parentheses next to means in table. Letters below means signify different groups of means, significant at the 0.05 level 
forester suggests that he has spent time building community capacity in forest management and that members can adequately monitor the forester's activities, trusting that management is proceeding according to regulations. On the contrary, a lack of trust in the forester may signify that heads of households are not aware of details of timber extraction activities and/or that they suspect the forester is cheating them. Both of these scenarios suggest weak interactions between the community members and the forester as well as low levels of involvement by the forester in community development activities.

Results show a clear relationship between communities with higher forestry types and trust in the forester, suggesting that communities may not be able to attain higher forestry types without positive interactions with external actors (Table 4). In addition, there is little difference between mean values in Michoacán and Oaxaca, unlike in the results of internal organization questions. Thus the manner in which foresters and community members interact in the two states may be similar.

Finally, using a composite variable of the six community governance questions (created using a simple average) and the trust in the forester variable, I conducted two separate linear regressions using a suite of independent variables that focused on education, ethnicity, income sources and natural resource consumption to analyze whether individual socioeconomic variables influence respondents' views about community governance or trust in foresters (Table 5). Results show some similar patterns for the two dependent variables: higher education levels, more subsistence production, fewer hectares owned (for governance) and less corn sold (for trust in foresters) are related to more positive perceptions of community governance and foresters. The one surprising result is that, while ethnicity is significant in both regressions, the sign changes. Individuals who speak an indigenous language are more likely to have positive perceptions of community governance and are also less likely to trust their forester. This may mean that strong relationships between indigenous people and foresters are more difficult to forge even though indigenous people seem

Table 4 Relationship with forester: results of factorial ANOVA by forestry type and state

Statement 4: I trust the forester that works in the community

\begin{tabular}{lll}
\hline Forestry type & Michoacán & Oaxaca \\
\hline 2 & $3.0(0.22)[\mathrm{a}]$ & $2.8(0.30)[\mathrm{a}]$ \\
3 & $4.2(0.18)[\mathrm{b}]$ & $4.4(0.18)[\mathrm{b}]$ \\
4 & $4.5(1.9)[\mathrm{b}]$ & \\
Forestry type main effect & $p<0.001$ & \\
State main effect & Not significant & \\
\hline
\end{tabular}

to have more positive attitudes about governance within the community.

These results begin to refute the notion that the level of vertical integration is related only to the strength of internal organization. First, strong internal governance is not always related to higher forestry types, which suggests that higher forestry types require something in addition to strong internal governance. Second, trust in the forester is significantly related to forestry type, suggesting the forester's potential role as a gatekeeper of community appropriation of forest management activities by providing capacity building for forest management, a topic that will be explored in the following section. Third, indigenous ethnicity is an important factor in determining lack of trust in foresters, implying that this barrier to trust must be overcome for higher levels of vertical integration to be achieved. Given that trust in foresters by level of vertical integration does not differ by state and yet Oaxaca has far more vertically integrated communities, I conclude that differences in the pools of external actors in the two states may contribute to Oaxaca's high level of community forestry development, rather than a difference in the quality of interactions between communities and foresters. While perhaps not perfectly conclusive on their own, these quantitative results set the stage for the qualitative analysis that follows.

\section{Analyzing the Relationship Between Communities and External Non-government Actors ${ }^{3}$}

\section{Oaxaca-Palo Verde (Type 4)}

Community Forestry History Palo Verde is one of the best known forestry communities in Mexico. It possess log trucks, a skidder, a saw mill, a wood drying kiln and a dozen small-scale carpentry shops, is the only study community that has attained FSC certification, and by all accounts is a model of forest management and community governance. Locals claim that out-migration has been reduced to nearly zero as a result of jobs created by the forestry program, the saw mill, and the carpentry shops.

Interactions with Non-government Actors Tracing the recent history of Palo Verde since the early 1980s shows the continued influence of external non-government actors who were interested in community development. In the early 1980s the community joined the Organization for the Defense of Natural Resources of the Sierra Juarez (ODRE-

\footnotetext{
${ }^{3}$ Due to space limitations, not all case study communities are discussed. Instead, key relationships are highlighted in certain communities.
} 
Table 5 Regression results: are individual characteristics related to perceptions of governance and trust in foresters?

\begin{tabular}{lll}
\hline Variable & Community governance composite & Trust in forester \\
\hline Age & $0.00(0.00)$ & $0.01(0.01)$ \\
Education level & $0.27 * * *(0.06)$ & $0.43 * *(0.17)$ \\
Indigenous language speaker & $0.31^{* * *(0.11)}$ & $-0.86^{* * *}(0.27)$ \\
Anyone in household living outside the municipality? & $0.07(0.10)$ & $0.35(0.30)$ \\
Agriculture is primary occupation & $0.04(0.10)$ & $0.11(0.27)$ \\
Hectares of individual usufruct land & $-0.03^{* *}(0.01)$ & $0.00(0.04)$ \\
Hectares of corn planted & $-0.01(0.03)$ & $-0.03(0.08)$ \\
$\%$ of corn sold & $-0.30(0.22)$ & $-1.43^{* *}(0.70)$ \\
$\%$ of food from subsistence & $0.12 * * *(0.04)$ & $0.28^{* * *}(0.10)$ \\
Owns refrigerator & $-0.10(0.11)$ & $0.09(0.28)$ \\
$\%$ domestic use timber from communal forest & $-0.03(0.03)$ & $0.00(0.09)$ \\
Use gas or firewood to cook? & $-0.05(0.07)$ & $0.04(0.18)$ \\
Constant & $3.30^{* * *(0.39)}$ & $1.52(0.95)$ \\
$R$ square adj & 0.30 & 0.12 \\
Observations (or sum wgts) & 261 & 141 \\
$F$ ratio & $10.48^{* * *}$ & $2.56^{* * *}$
\end{tabular}

NASIJ), an umbrella organization of local indigenous communities that pressured the federal government to grant control of forest resources to communities. ODRENASIJ was created by forest communities and requested the support of student activists from Mexico City. This is how the two-decade relationship between Palo Verde and a core group of outsiders began. After winning the struggle against the concessions, the activists helped the community obtain funding from the Rockefeller Foundation and provided technical assistance that focused on capacity building, community organizing, and participatory planning. Eventually the activists formed several NGOs that have become leaders in the country in participatory rural development, based primarily on their experiences with Palo Verde and nearby communities (Chapela and Lara 1996; Chapela Mendoza 1999). As local capacity grew, the community formed a union with three other communities in the region and took on complete responsibility for timber extraction activities. In the meantime, the NGO took on a peripheral role by helping to develop new projects and obtaining international funding. An indication of the importance of these external actors in forming local forest governance is that Palo Verde had no internal rules for forest use prior to the beginning of community forestry. According to an older community member, roughly 25 years ago many locals made a living by cutting wood shingles for home construction with no limits on how much they could cut and no rules for requesting permission from local authorities, all of which exist today. These rules are now enforced by the community but required the help of external actors dedicated to community development activities to create them. As a forester and community member of a neighboring community said, "We always saw it was necessary to have the community, foresters, and an NGO that would guide the process."

\section{Oaxaca-Santa Maria Picachos (Type 2)}

Community Forestry History Santa Maria Picachos, a 30 min drive from Palo Verde, is a Type 2 community and contracts all forestry activities with timber companies. Its forests were logged by the same parastatal timber company that worked in Palo Verde. However, they did not join the ODRENASIJ in the early 1980s, perhaps because the community is located slightly farther away than Palo Verde from most member communities. Even after state-sponsored timber concessions ended, the parastatal timber company continued to harvest timber in Picachos through a direct agreement with the community. Eventually the parastatal timber company left the region and was replaced by smaller timber companies. Community members I spoke with have little recollection of exactly which timber company harvested in which years. This lack of knowledge seems indicative of the general removal of community members from forestry activities. Yet despite low capacity in forest management, the community owns and operates a bus line to Oaxaca City, a type of community business that does not exist in any Type 2 case study communities in Michoacán. Thus, one must question 
why existing community capacity has not been applied to forest management.

Interactions with Non-government Actors For the past 10 years, Picachos has used the services of a private forester from Oaxaca City. According to several government officials, the forester working in Picachos is one of the least respected foresters in the state because attention is given to maximizing timber harvest and little or no effort is made for capacity building. According to one community member,

The forester doesn't tell us that there are programs.

He's pegged to the timber company. Only when the

president of the community went himself to see did we find out....We wanted to get a mini-saw mill but we didn't know how to do it....There's no one that knows here....We haven't fought with him because we don't want problems. (Community member, Santa Maria Picachos)

Picachos' forester has never provided trainings or applied for a development subsidy on behalf of the community or, according to government records, for any of the communities in which he works. When one timber company terminates work in the community, the forester, rather than the community, finds another, which places more control in the hands of the forester. Several community members noted that in timber harvest areas only pine trees are harvested and oaks, which have little market value, are left behind. Most forests in Mexico are managed under a selection strategy in which trees of all species are removed based on their existing distribution in order to maintain diversity and timber value. Harvesting only pine trees can lead to low regeneration because they are shade intolerant and heavy shade from oaks and other broadleaved species does not allow regeneration (Musalem 1972; Snook 1986), and locals' anecdotal reports of changes in forest composition confirm this pattern. Thus, the lack of an external actor interested in promoting community involvement may be leading to forest degradation and limited economic benefits for community members.

\section{Oaxaca-El Rincon (Type 1)}

Community Forestry History The community of El Rincon, a 45 min drive from both Palo Verde and Picachos, has no forestry permit. According to survey results, they also have a higher percentage of indigenous language speakers, and the community is also slightly farther from Oaxaca City than the other communities. They have had intermittent harvesting of a section of forest that burned in forest fires in
1998 and 2001, although this is not a formal timber management plan.

Interactions with Non-government Actors The reputation of the timber company that has harvested the burnt areas in El Rincon is even worse than that of Picachos' forester. Locals mentioned that the owner brings different foresters each visit and no efforts are made in community development activities. Locals complain that trees unaffected by forest fires are often felled. A community member quoted the timber company owner as saying, "Do you want your potatoes? Well then let's cut that one too." The community is paid roughly $70 \%$ of the price per cubic meter that other communities in the region attain, but they were unaware of this discrepancy. On the other hand, El Rincon's internal governance in other matters seems quite strong. The most striking example is the community's sewage system, which is the most advanced of any of the 11 case study communities. Community members, under the guidance of government health officials, collected funds from residents to build a sewer and filtration system, and required each family to buy a toilet. Thus, El Rincon has the capacity to organize as well as the ability to adapt local rules to the suggestions of external actors. Strong internal organization may be necessary for these projects, but it is not sufficient; external actors are also critical.

\section{Michoacán-El Oyamel (Type 3)}

Of the four communities with a forestry program in Michoacán, three have the same forester. According to several government officials, NGOs, and foresters, the forester that works for these three communities is not trustworthy. How did El Oyamel, a Type 3 community, manage to attain a higher level of vertical integration, and why do they continue to work with and trust this forester?

Community Forestry History El Oyamel began its forestry program in the mid-1980s, in the same period that other Mexican success stories organized to manage common forests. It is a relatively new community, formed in 1978, and its founders petitioned the federal government for land with the intention of using it for forestry. The community's initial desire for community forestry seems key to the advances it has made. Indeed, El Oyamel has a level of internal organization comparable to Oaxaca communities according to survey results.

Interactions with Non-Government Actors While private foresters have worked continuously with the community, El Oyamel has also had extensive support from government agencies and NGOs. Today, two NGOs work with El 
Oyamel, one to build capacity for forest vigilance to deter wood theft and another on a nursery to produce saplings for reforestation using locally harvested seeds. Through these experiences and others, the community has learned enough about forest management to monitor their forester and thus trust his work. According to one community member:

I saw that the marking [of trees for felling] wasn't going well, it was illegal. [He] was marking all the straightest and biggest trees, and leaving the ones with a lot of branches and bad ones. And parts [of the cutting area] were cut too thinly. I told him that it shouldn't be like that... that's when we agreed in our [biweekly] meeting that we need to invite that forester to sit him down and tell him that it shouldn't be like that. That's when he said that [the timber buyer] was obligating him. We said, 'No, you can't be obligated by anybody else. You work out your relations with other people and don't take things away from us. Because if not we'll fire you and get another forester.' He said, 'No, no, I'll mark well, I'll take of you.' He denied it, but we knew it was happening, and now it's better, it's normal. (Community member, El Oyamel)

\section{Michoacán—La Capilla (Type 2)}

Community Forestry History La Capilla, a Type 2 community, has been managing its forest with limited participation by community members for nearly 20 years. Community members rarely go to the forest, have no vigilance program, and merely await payment following the timber harvest. During one visit to the community, the president of the community called a meeting in order to present my research program to the community. According to other community members, it was the first community meeting in over a year and only one third of members attended.

Interactions with Non-government Actors Following this meeting, the president began collecting signatures on a typed sheet of paper which had been composed by their forester, who is the same one that works in El Oyamel. The paper claimed that two weeks prior there had been a meeting with the majority of community members in attendance during which the forester presented a project to obtain a government subsidy for the forestry program. In fact there had been no meeting and community members did not know the intent of the subsidy that the forester was soliciting on their behalf. This had occurred in two prior years and the community had given signatures, but never saw subsidy money enter the community. The commonality of this practice was confirmed by an NGO worker with several years of experience soliciting government funds on behalf of communities.

In some communities there is interest from the community and they asked for you as a consultant. In other cases, they give their signatures because they know they are going to get something, not knowing what it is going to be. There is no intent to organize so that the investment will continue. There is no one with commitment to do follow-up. [The external actor] is committed because he is paid [a percentage of the grant]. (NGO worker in Michoacán)

\section{Michoacán—Las Lomas (Type 2)}

Interactions with External Actors A final example in Michoacán shows how CDO actors can aid in the process of capacity building while simultaneously teaching the community to be vigilant of the activities of foresters. The community of Las Lomas initiated its forest management program in 2002 with the help of a local NGO, the Grupo Interdisciplinario de Technología Rural Apropiada (GIRA). GIRA's role was to organize the creation of a community land use plan, which involved demarcating all communal forest lands and individual agricultural plots with GPS units, facilitating group decisions on management of communal lands, and designing rules to monitor and enforce these decisions. Ongoing work with GIRA has focused on training community members in forest management activities, including felling timber, monitoring bark beetle infestation, and measuring the quantity of lumber felled. During the period that the community worked with GIRA, the community fired two foresters, one of whom manages the forests of El Oyamel and La Capilla. On both occasions, community members did not trust that the forester was managing timber extraction fairly and sustainably. Without the knowledge that GIRA provided to the community, they may not have had the awareness to take these actions, underscoring the importance of CDO actors. Staff at GIRA suggest that it may be impossible to trust any forester in the state, and they therefore advocate community monitoring of the foresters' activities.

The Landscape of External Actors in Michoacán and Oaxaca

Case study communities in Michoacán have both a lack of strong internal organization and a lack of external nongovernment actors motivated to conduct community devel- 
opment activities. The perception among forest professionals in Michoacán is that private foresters continue to dominate the process of forest management.

The communities never have been able to appropriate their resources. It's difficult for them to apply for funds, to sell [their timber on their own]. They don't have a culture of commercialization or organization. So [a private forester] represents the community. They have the community threatened. 'If you contract with other [foresters], then I'm not going to buy your wood.' When in reality they could sell their wood at a better price elsewhere. (Government worker in Michoacán)

The landscape of foresters in Oaxaca, while perhaps better than that of Michoacán, has many of the same characteristics. In Michoacán, one NGO worker commented that, of the private foresters in the states, "none have commitment to the community," and in Oaxaca an NGO worker said that finding committed foresters is "like searching for a needle in a haystack." The difference in Oaxaca is that

[Private foresters] have lost presence and political control because the situation of forests in Mexico is a disaster and they have never created a solution that wasn't corruption.... [In Oaxaca, NGO workers with training as] geographers, biologists, anthropologists, sociologists have been able to enter in this new scenario and suggest more social strategies. But this control in Michoacán hasn’t permitted it. (NGO worker in Oaxaca)

In Oaxaca, interviewees also lauded hybrid organizations composed of foresters and community development professionals. "The creation of these technical service groups....have made a cut in the vertical control that private foresters have had in the past in the country.... These have been rehearsed here and have been used as a platform in other states for forest management on a more community level" (NGO worker, Oaxaca). While the distinction between the two states is clear, it is important to note that the situation is not black or white; the range of external non-government actors exists in both states.

\section{Vicious and Virtuous Cycles-The Bottleneck of External Non-government Actors}

I have shown that external non-government actors influence the formation of community capacity for forest management and that the pool of these actors in Oaxaca offers more prospects for community development than that of Michoacán. How does the interaction between communities and external non-government actors create self-reinforcing development in some cases and self-reinforcing stagnation in others?

Incentives and Motivations

As mentioned above, timber extraction oriented (TEO) actors are motivated to maximize timber harvests. A community development oriented (CDO) actor in Oaxaca made the following comment about his arrival to forestry school in the late 1970s: "A student [from the forestry school] asked me why I came here to study. I said because I like the forests... [He said,] 'No, we come here come because we want to make money. We are interested in the forest to make money." Although a TEO actor is officially employed by the community and paid through timber sales, the timber company often pays the TEO actor directly, subtracting this payment from the total value of timber bought from the community. In effect then, the TEO actor is employed by the timber company. The timber company is interested in obtaining the most wood of the best quality, rather than removing damaged or crooked trees to improve the genetic stock of the forest. Thus the interests of TEO actors and timber companies are similar, and the incentive for the forester to mismanage the forest is evident. The community, the owners of the resource, is the only actor that may have a long-term interest in the quality of the forest, but without management knowledge and organization for monitoring, it is likely that mismanagement will be allowed to occur. Although management plans regulate the quantity of timber extracted, government oversight of this process is weak and third party certifiers such as the FSC focus on communities that can demonstrate sustainability, rather than monitoring activities in communities that do not meet the high standards required for certification. To maintain this position of control over timber, a TEO actor may be uninterested in informing the community about potential funding opportunities that focus on capacity building, as occurred in several case study communities. In addition, the TEO actor is motivated to guard this lucrative position by attempting to prevent other nongovernment actors from entering the community. Interviewees referred to this as 'territoriality,' which is often maintained by TEO actors exploiting paternalistic relationships with communities. As such, TEO actors would prefer to work in communities with weak internal organization, representing the vicious cycle in which many communities are unable to gain the skills required to create Type 3 and 4 forestry programs.

In the case of $\mathrm{CDO}$ actors, there is less potential for mismanagement of forests because these actors are motivated to produce successful communities, rather than to maximize timber harvests. However, CDO actors' motiva- 
tions may be detrimental to the general development of Type 1 and 2 communities because "NGOs need to have prestige in order to continue their work" (CDO actor in Oaxaca). CDO actors may have a strong incentive to secure well-paying work for their firm and a desire to receive public praise as a means of advertising their skills and expertise (Ostrom et al. 2002). Because of this motivation, $\mathrm{CDO}$ actors may prefer to work in communities that already have successful projects because there is a higher chance of continued success. This creates an incentive to promote projects in communities with higher levels of vertical integration and continue work in these same communities rather than approach Type 1 or 2 communities that may have a higher risk of failure and may therefore not generate the prestige and success necessary for CDO career advancement. Hence, a virtuous cycle is created in which successful communities continue to receive assistance. A similar process was documented in the Andean highlands, in which demand for poverty reduction impact led to increased focus on families with less need but among whom change could be achieved (Bebbington 2004).

In fact, the availability of communities with strong internal governance may be a key reason why there are so many more CDO actors in Oaxaca than in Michoacán. Not surprisingly, a sharp rise in overall NGO activity has been documented in Oaxaca, from about 30 NGOs in 1985 to over 200 in 1999 (Moore et al. 2007). The head of a large CDO organization in Oaxaca stated that, "I am from Michoacán and I would never have thought of starting an NGO in Michoacán because there is much more control and presence of the government in rural issues that tolerates irregular management of forests." This pattern has occurred in the past in Mexico when the Mexico-Germany Partnership, the organization that initiated community forestry in tropical forests in Mexico in the 1980s, abandoned Chiapas after two years and reestablished in Quintana Roo because entrenched interests made it difficult to make progress (Vargas-Prieto 1998). This geographically uneven NGO activity is not unique to Mexico and has been documented at all scales-between continents and countries, within countries, and between communities - the results of which can reinforce existing inequalities in development (Mercer 2002; Bebbington 2004).

External non-government actors necessarily operate within and may have evolved in response to the existing framework of government regulation. This may help explain why the existing pool of external actors in each region varies. Thus, to understand successes and failures of community-based natural resource management, it is important to understand not only the activities of external non-government actors, but also the policy climate within which they operate.
This analysis provides some clues to explain the two directions in the growth of community forestry over the past two decades mentioned in the "Introduction": stronger communities continue to develop because they know how to attract $\mathrm{CDO}$ actors, maintain relationships with them, and receive ongoing assistance from them. More communities are attaining forestry permits because TEO actors have an interest in increasing their timber harvests portfolio; however these communities rarely advance beyond Type 2 because of a lack of interest in community development activities.

\section{Path Dependency and Cycles}

The motivations of non-government actors not only help determine which communities receive different types of assistance; they also create and reinforce institutions in communities that are either receptive or mistrusting of external assistance. Because there are few opportunities to connect to external resources, each encounter with an external actor solidifies the community's perception of external actors. Ostrom (1990) calls this incremental learning, and additional costs to change institutions, termed transformation costs, may be incurred as a result of this learning. In general, trust, reciprocity, and cooperation create feedback loops, and can be seen as complex adaptive systems in which insignificant circumstances become magnified. Thus, if interactions with external actors lead to benefit for the community, future interactions are likely to be sought. For example, in Palo Verde, a community organizing group call Juventud Campesino was started by a primary school teacher from outside the community in 1970s, which some older community members said contributed to the community's later willingness to look for external support. On the other hand, in Picachos, after two decades of negative experiences with TEO actors, there is little expectation that external actors will provide benefits. Thus, once a relationship is established with an external nongovernment actor, the relationship becomes selfreinforcing, and vicious or virtuous cycles begin to form which are difficult to undo.

\section{Conclusion}

This analysis has uncovered important clues as to why there has been little progress in creating more Type 3 and 4 communities over the past 15 years and why forest degradation continues to occur in communities with forest management permits. As mentioned above, I do not claim that external actors are the only key to successful community forestry programs; internal community gover- 
nance is a necessary component of commons management, but it is not sufficient.

Unless communities can internalize timber extraction and community development activities, external nongovernment actors will be critical in community forestry, and therefore must be considered in creating development strategies. Government sponsored forestry development programs that do not recognize that external nongovernment actors may be uninterested in community development activities will not create desired outcomes. Given these conclusions, in designing future programs for community forestry development, funds should be made available specifically for promotion and training in Type 1 and 2 communities. These funds should not be tied to specific communities (to avoid territoriality issues), nor should future funding be based on the success of projects (to avoid NGO risk aversion). These projects should be awarded only to organizations staffed with specialists trained in community development. In addition, forestry subsidies for timber extraction activities should only be granted with the stipulation that community development trainings are also implemented. Trainings should be given by trained professionals rather than foresters with no background in community development. Finally, foresters must become qualified in community development activities, potentially through required training programs.

In conclusion, by looking outside the community a new understanding of commons management can emerge. Not only are communities embedded in a larger political economy, they are connected to it through external nongovernment actors. These actors have a range of motivations for engaging with forest communities, and analyzing these motivations leads to an understanding of why their impacts on community appropriation of forest management can lead to different outcomes.

Open Access This article is distributed under the terms of the Creative Commons Attribution Noncommercial License which permits any noncommercial use, distribution, and reproduction in any medium, provided the original author(s) and source are credited.

\section{References}

Agrawal, A. (2001). Common Property Institutions and Sustainable Governance of Resources. World Development 29: 1649-1672.

Altman, I., and Lockhart, J. (eds.) (1976). Provinces of Early Mexico, UCLA Latin American Center Publications, University of California, Los Angeles

Antinori, C. M. (2000). Vertical Integration in Mexican Common Property Forests. In: Agriculture and Resource Economics. University of California, Berkeley.

Antinori, C., Magaña Torres, O., Torres Rojo, J. M., Segura Warnholtz, G., and Bray, D. B. (2004). New interdisciplinary research on Mexico's common property forests: a national survey. In: The Commons in an Age of Global Transition: Challenges, Risks and Opportunities, the Tenth Conference of the International Association for the Study of Common Property, Oaxaca, Mexico, August 9-13.

ASETECO (2002). Una Caminata de Viente Años en los Bosques Comunales de Oaxaca. ASATECO, A.C., Oaxaca.

Bebbington, A. (2004). NGOs and Uneven Development: Geographies of Development Intervention. Progress in Human Geography 28: $725-745$.

Bray, D. B. (2000). Adaptive Management, Organizations and Common Property Management: Perspectives from the Community Forests of Quintana Roo, México. In: Eighth Biennial Conference of the International Association for the Study of Common Property. Bloomington, Indiana.

Bray, D. B., and Merino, L. (2004). Los bosques comunitarios de México. Logros y desafíos. Ford Foundation, Mexico City.

Bray, D., Merino-Perez, L., Negrero-Castillo, P., Segura-Warnholtz, G., Torres-Rojo, J. M., and Vester, H. F. M. (2003). Mexico's Community-Managed Forests as a Global Model for Sustainable Landscapes. Conservation Biology 17: 672-677.

Bray, D. B., Ellis, E. A., Armijo-Canto, N., and Beck, C. T. (2004). The Institutional Drivers of Sustainable Landscapes: a Case Study of the 'Mayan Zone' in Quintana Roo, Mexico. Land Use Policy 21: 333-346.

Bray, D., Merino-Perez, L., and Barry, D. (eds.) (2005). The Community Forests of Mexico, University of Texas Press, Austin.

Chance, J. K. (1989). Conquest of the Sierra: Spaniards and Indians in Colonial Oaxaca. University of Oklahoma Press, Norman.

Chapela, F. M., and Lara, Y. P. (1996). La Planeación Comunitario del Manejo del Territorio. Consejo Civil Mexicano para la Silvicultura Sostentables, A.C., Mexico City.

Chapela Mendoza, F. (1999). Silvicultura Comunitaria en la Sierra Norte de Oaxaca: El caso de la Union Zapoteco-Chinanteco. Red de Gestion de Recursos Naturales y Fundacion Rockefeller, Mexico City.

de la Peña, G. (1992). Populism, regional power, and political mediation: southern Jalisco, 1900-1980. In Van Young, E. (ed.), Mexico's Regions: Comparative History and Development. Center for U.S.-Mexico Studies, UCSD, San Diego.

de Vries, P. (2002). Vanishing Mediators: Enjoyment as a Political Factor in Western Mexico. American Ethnologist 29: 901-927.

FSC. (2007). In: Forest Stewardship Council German Working Group. http://www.fsc-info.org/.

Galeote, M. (2006). Interview. In: Barsimantov, J. (ed.), Oaxaca City.

Gibson, C. C., McKean, M. A., and Ostrom, E. (2000). People and Forests: Communities, Institutions, and Governance. MIT Press, Cambridge.

Haley, M., and Clayton, A. (2003). The Role of NGOs in Environmental Policy Failures in a Developing Country: the Mismanagement of Jamaica's Coral Reefs. Environmental Values 12: 29-56.

Jardel, E. J. (1998). Efectos ecologicos y sociales de la explotacion maderera en los bosques de la Sierra de Manantlan. In Ávila, R., Emphoux, J. P., Gastélum, L. G., Ramirez, S., Schöndube, O., and Valdez, F. (eds.), El Occidente de Mexico. Universidad de Guadalajara, Guadalajara.

Jardel, E. J. (2006). Viejos y nuevos problemas en el sector forestal en Mexico. In: Seminario G-Bosques, October 6, 2006, Mexico City, Mexico.

Klooster, D. (2003). Forest Transitions in Mexico: Institutions and Forests in a Globalized Countryside. The Professional Geographer 55: 227-237.

Marshall, E., Newton, A. C., and Shchreckenberg, K. (2003). Commercialization of Non-timber Forest Products: First Steps in Analysing the Factors Influencing Success. International Forestry Review 5: 128-137. 
McCay, B. J., and Jentoft, S. (1998). Market or Community Failure? Critical Perspectives on Common Property Research. Human Organization 57: 21-29.

Mercer, C. (2002). NGOs, Civil Society, and Democratization: a Critical Review of the Literature. Progress in Development Studies 2: 5-22

Merino, L. (2004). Conservación o Deterioro. El impacto de las políticas públicas en las instituciones comunitarias y en los bosques de México. Institito National de Ecologia, Mexico City.

Meyer, C. A. (1995). Opportunism and NGOs: entrepreneurship and green north-south transfers. World Development 23: $1277-1289$.

Moore, S., Winders, J., Frohling, O., Jones, J. P., and Roberts, S. M. (2007). Mapping the grassroots: NGO formalisation in Oaxaca, Mexico. Journal of International Development 19: 223-237.

Musalem, F. J. (1972). Breve analysis sobre la silvicultura y manejo de bosques de coniferas en Mexico. Mexico y Sus Bosques 2132.

Navia Antezana, J. (2006). Interview. In Barsimantov, J. (ed.), Uruapan, Michoacán.

Olson, M. (1965). The Logic of Collective Action: Public Good and the Theory of Groups. Harvard University Press, Cambridge.

Ostrom, E. (1990). Governing the Commons: the Evolution of Institutions for Collective Action, Cambridge University Press, Cambridge.

Ostrom, E., Gibson, C. C., Shivakumar, S., and Andersson, K. (2002). Aid, Incentives, and Sustainability. In: Sida Studies in Evaluation. Sida, Stockholm.

Pagdee, A., Kim, Y., and Daugherty, P. J. (2006). What makes community forest management successful: a meta-study from community forests throughout the world. Society and Natural Resources 19:33-52.

Pimentel Ramirez, J. L. (2005). La Industria Forestal en el Estado de Michoacán. In: Morelia. Comision Forestal de Michoacán, Mexico.

Poteete, A. R., and Ostrom, E. (2004). Heterogeneity, group size and collective action: the role of institutions in forest management. Development and Change 35: 435-461.
SEMARNAT. (2004). Anuario estadistico de al producción forestal 2004. In, Mexico City.

Snook, L. (1986). Effects of Mexico's selective cutting system on pine regeneration and growth in a mixed pine-oak (Pinus-Quercus) forest. In: USDA Forest Service General Technical Report, pp 27-31. USDA.

Taylor, P. (2000). Producing More with Less? Community Forest in Durango, Mexico in an Era of Trade Liberalization. Rural Sociology 65: 253-274.

Taylor, P. L. (2003). Reorganization or Division? New Strategies in Community Forestry in Durango, Mexico. Society and Natural Resources 16: 643-661.

Taylor, L., and Zabin, C. (2000). Neoliberal Reform and Sustainable Forest Management in Quintano Roo, Mexico: Rethinking the Institutional Framework of the Forestry Pilot Plan. Agriculture and Human Values 17: 141-156.

Tucker, C. M. (2004). Community Institutions and Forest Management in Mexico's Monarch Butterfly Reserve. Society and Natural Resources 17: 569-587.

Vargas-Prieto, A. M. (1998). Effective Intervention: External and Internal Elements of Institutional Structure for Forest Management in Quintana Roo. Mexico University of WisconsinMadison, Madison.

Velazquez, A., Mas, J. F., Diaz-Gallegos, J. R., Mayorgo-Saucedo, R., Alcantara, P. C., Castro, R., Fernandez, T., Bocco, G., and Palacio, J. L. (2002). Patrones y tasas de cambio del uso del suelo en Mexico. Geceta Ecologica 62: 21-37.

Velazquez, A., Torres, A., and Bocco, G. (eds.) (2003). Las enseñanzas de San Juan: Investigación participativa para el manejo integral de recursos naturals, Instituto National de Ecologia, Mexico City.

Wade, R. (1988). Village Republics: Economic Conditions for Collective Action in South India: Cambridge University Press, Cambridge.

World Bank (1995). Mexico Resource Conservation and Forest Sector Review. World Bank, Washington.

Yates, P. L. (1981). Mexico's Agricultural Dilemma. University of Arizona Press, Tucson. 